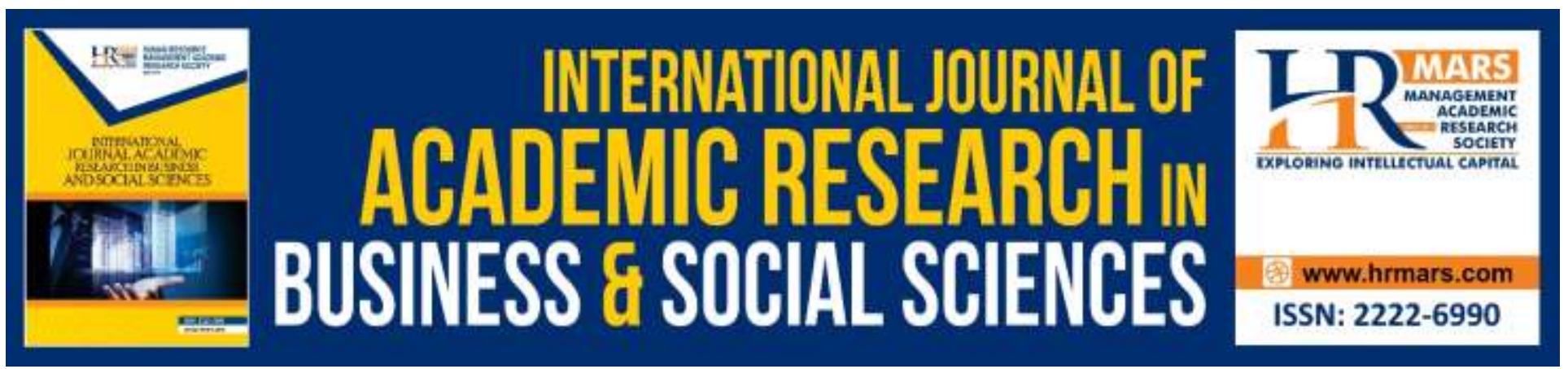

\title{
The Impact of Inflation Towards Foreign Direct Investment in Malaysia And Iran
}

Teh Yi Hong, Dayang Haszelinna Abang Ali

To Link this Article: http://dx.doi.org/10.6007/IJARBSS/v10-i6/7280
DOI:10.6007/IJARBSS/v10-i6/7280

Received: 10 April 2020, Revised: 12 May 2020, Accepted: 30 May 2020

Published Online: 13 June 2020

In-Text Citation: (Hong \& Ali, 2020)

To Cite this Article: Hong, T. Y., \& Ali, D. H. A. (2020). The Impact of Inflation Towards Foreign Direct Investment in Malaysia And Iran. International Journal of Academic Research in Business and Social Sciences, 10(6), 210216.

Copyright: (c) 2020 The Author(s)

Published by Human Resource Management Academic Research Society (www.hrmars.com)

This article is published under the Creative Commons Attribution (CC BY 4.0) license. Anyone may reproduce, distribute, translate and create derivative works of this article (for both commercial and non-commercial purposes), subject to full attribution to the original publication and authors. The full terms of this license may be seen at: http://creativecommons.org/licences/by/4.0/legalcode

Vol. 10, No. 6, 2020, Pg. 210 - 216

Full Terms \& Conditions of access and use can be found at http://hrmars.com/index.php/pages/detail/publication-ethics 


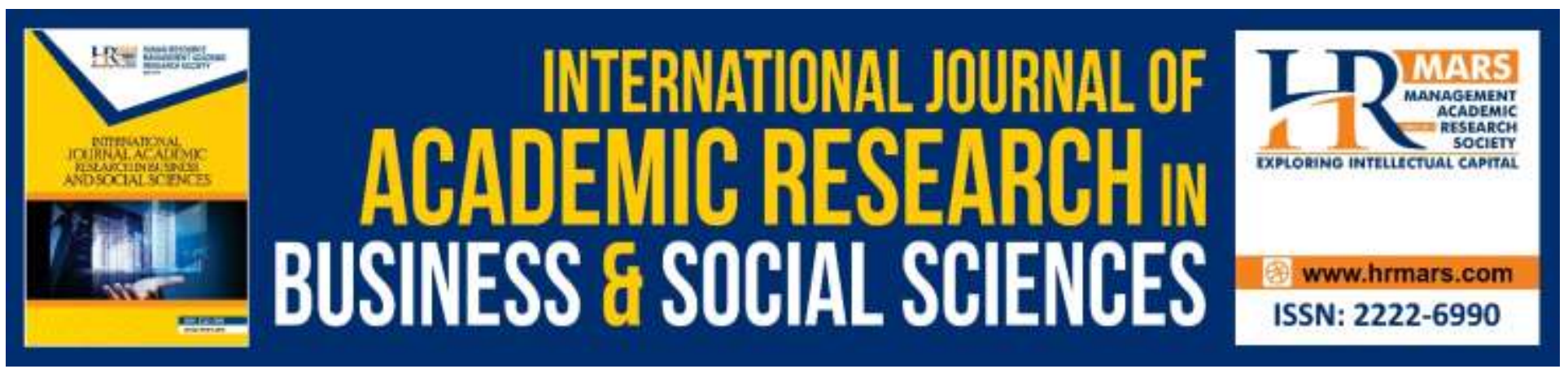

\title{
The Impact of Inflation Towards Foreign Direct Investment in Malaysia And Iran
}

\author{
Teh Yi Hong \\ Faculty of Economics and Business, Universiti Malaysia Sarawak \\ Email: yihong_1195@outlook.com
}

\author{
Dayang Haszelinna Abang Ali \\ Centre for Policy Research and International Studies, Universiti Sains Malaysia \\ Email: dyghaszelinna@usm.my
}

\begin{abstract}
This study examines the effect of inflation towards the foreign direct investment in Malaysia and Iran. The testing period for this study are ranges from year 1986 to 2016. The Augmented-Dickey Fuller (ADF) unit root test was used to test the stationary of variables, the exist of cointegration variables was tested by Johansen and Juselius test, Granger causality based on VECM framework was used to test the short run and long run relationship between variables and lastly the variance decomposition was conducted to test the variable are exogenous or endogenous. From the empirical results, it has shown the foreign direct investment has effects on gross domestic product in short run in Malaysia meanwhile in Iran there are no causality relation among the variables in short run.
\end{abstract}

Keywords: Inflation, Foreign Direct Investment, Malaysia, Iran, Time Series Analysis

\section{Introduction}

Foreign direct investment (FDI) plays an important role which able to affect the economic growth of a country, especially for those developing countries as the inflow of FDI can stimulate the economic with the capital, technology, and skilled labor gained from abroad countries. Hence, started from 1990s, the FDI has become an important source of external finance for those developing countries. According to Khan and Mitra (2014), the study declare that high level of inflation rate will damage the economic activities which resulting in a decrease of capital inflow. Besides, a high level of inflation rate also affects the capital preservation of foreign investment, can caused the confidence of abroad investor decrease, and therefore it will decrease the net inflow of FDI. Malaysia and Iran which both are developing country but have different level of inflation rate, and reason behind for choosing these two countries is to investigate how the level of inflation rate will affect to the net inflow of FDI. The inflation rate of Iran exceedingly higher than the inflation rate of Malaysia, hence it is able to compare which level of inflation is more attractive for the inflow of FDI. 
INTERNATIONAL JOURNAL OF ACADEMIC RESEARCH IN BUSINESS AND SOCIAL SCIENCES

Vol. 10, No. 6, June, 2020, E-ISSN: 2222-6990 @ 2020 HRMARS

The phenomenon of inflation refers to the overall price of the goods and services in the economy has increased over a period of time. Inflation incarnate reduction of the purchasing power as the increase of price level will cause every unit of currency purchase fewer goods and services. It can be described as a two-edged sword as it can be beneficial or negatively affect to the economy. When inflation is too high, it will cause the economic recession; however when inflation is managed maintain at a moderate level, it may help the economy upturn. In Malaysia, the increase of inflation rate is regarding in $0.3 \%$ to $5.5 \%$ which consider in a stable level. While the inflation rate in Iran is increasing in two digits annually which indicate that Iran has faced a high inflation problem. The phenomenon of high inflation will result in a downturn of economy, the low purchasing power due to the inflation will reduce the aggregate demand or total demand in market. People who have low purchasing power are afford to buy fewer goods and services, hence they will less demand for it. Yet, due to the less spending of money, it causes decline in gross domestic product. Consequently, abroad investor will decide to reduce the investment to those countries so that they can reduce the risk of their invested capital which may unable to generate their targeted profit.

Furthermore, theoretically the inflation is referred to a general increase of price level and it will obstructs inflow of FDI when it is in a high inflation level; while it will attract the net inflow of FDI if the inflation are stable or known as low inflation rate. Most of the researcher found that the FDI and inflation rates is negatively related. According to ÇEviŞ and Camurdan, 2007; Kok and Acikgoz Ersoy 2009; Valli and Masih 2014, their research found that the inflation rate is negatively associated with FDI. However, from the data obtained from World Bank, the inflation rate of Iran in year 2013 to 2015 shows that decreasing of inflation rate which from 39.26 to 13.705, the net inflow of FDI also shows that decrease from USD\$ 3.049 billion to USD\$2.05 billion. In Malaysia, there is also show the same situation when inflation rate in year 2011 drop from 3.2 to 1.647, the net inflow of FDI also decrease from USD\$15.119 billion to USD\$ 8.895 billion. By the data obtained, the actual findings shows that theory and realistic have a difference kind of result. On the other spectrum, there are no previous studies that are linked to inflation rate and foreign direct investment with comparison of two countries which are Malaysia and Iran. The study will able to compare the level of inflation from two countries which one of the inflation fluctuate while another level of inflation is stable in the same sample period and how it affects to the foreign direct investment of their countries. As there is lack of research on the relationship between level of inflation rate and net inflow of FDI, hence through this study, it can led to a better understanding and able to determine how significant the impact level of inflation rate can influence the FDI. Thus, this study is aimed to examine the relationship between inflation rate and foreign direct investment with using the latest data set. In addition, this study also include GDP and exchange rate as the independent variables.

\section{Literature Review}

Onyeiwu and Shrestha (2004) explore whether the stylized determinants of FDI affect FDI flows to Africa in conventional ways. This study has used panel data analysis and the dependent variable are FDI, GDP growth rate, inflation rate, real interest rates, openness of the economy, international reserves, external debt, taxes, political rights, infrastructures, and natural resource availability. The methodology used in this study are fixed and random effects models. The findings show the variables which significant on FDI flows to Africa are economic growth, inflation, openness of the economy, international reserves, and natural resource availability. However, it founds that political rights and infrastructures are not significant to FDI flows in Africa. 
INTERNATIONAL JOURNAL OF ACADEMIC RESEARCH IN BUSINESS AND SOCIAL SCIENCES Vol. 10, No. 6, June, 2020, E-ISSN: 2222-6990 @ 2020 HRMARS

According to the study of ÇEviŞ and Camurdan (2007), the objective of this study is to exploit an empirical framework to assess the economic determinants of FDI inflows through the use of panel data of 17 developing countries and economies in transition. The independent variables used in the study are the previous period of FDI, GDP growth, wage, trade rate, the real interest rates, inflation rate and domestic investment. The methodology used in the study are Panel Unit Root Tests, GLS (generalised least squares), Lagrange Multiplier test, Hausman test and fixed effect model. The findings reveal that there are positive correlation between FDI and variables which are interest and growth rate, trade rate, and the previous period FDI. However, the study found that inflation rate is negatively related with FDI. The major economic determinants of FDI inflows are inflation rate, trade rate, and rate of interest and GDP growth.

The purpose of Ang (2008)' research was to examine the determinants of FDI for Malaysia over the period of 1960 to 2005 . The dependent variable in this study is inflows of foreign direct investment while the independent variable are financial development, annual growth rate of GDP, infrastructure development, trade openness, real exchange rate, statutory corporate tax rate, and macroeconomic uncertainty related to output fluctuations. This study has use 2SLS approach by using the first lags of the variables as instruments for the current differenced terms to account for the problems of endogeneity bias. The finding reveals positive relationship between GDP growth rate, development of financial and infrastructure, and trade openness with FDI. The greater uncertainty of macroeconomic will encourage more inflow of FDI, on the other hand whereas, the findings shows increase statutory corporate tax rate and real exchange rate seems to be prevent the inflow of FDI.

According to Wijeweera and Mounter (2008), the study was to examine the long-run effects on Sri Lanka's FDI inflows from changes in key macroeconomic variables of interest. The times series data for period 1950-2004 has been use in this study. The variables used in this study are foreign direct investment inflows, market size and performance, openness indicator, labour cost indicator, exchange rate, and interest rate. This study used unit root test, impulse response functions (IRF), forecast error variance decompositions (VDC), and vector autoregressive methods (VAR) to examine how FDI inflows respond to different macroeconomic variables. The study reveals that in the five considered variables, wage rate is the most important determinant of inbound FDI to Sri Lanka, positive long-run relationships were found between FDI and real GDP, and between FDI and previous levels of FDI. The open trade was found to exert a positive influence on FDI inflows while increase of domestic interest rate has negative influence to FDI inflows.

Kok and Acikgoz Ersoy (2009) investigate the best determinants of foreign direct investment (FDI) that show the capital flows to developing countries in a globalization framework. The study has based on the panel of data (FMOLS-fully modified OLS), cross-section SUR (seemingly unrelated regression), and unit root test for 24 developing countries, over the period of 1983-2005 for FMOLS and 1976-2005 for cross-sectional SUR. The study found that the communication variable is the main determinants of FDI, and there is a negative impact between the reciprocal action of FDI with total debt service/GDP and inflation. Yet, the study also reveals in developing countries, there are strong positive effect of interaction of FDI and some determinants of FDI on economic progress.

The study of Choong and Lam (2010) has re-examines the determinants of foreign direct investment (FDI) in Malaysia, for the period of 1970-2006. This study employ the time series data and the independent variables are literacy rate, openness, real GDP of Malaysia and real GDP of China, while dependent variable is FDI inflows. Augmented Dickey Fuller (ADF), unit root tests, Phillips Perron's (PP) Z tests, Granger causality, Vector Autoregressive (VAR) Model and Vector Error 
Correction Model (VECM) are employ as the methodology in this study. The results reveals that a higher growth rate of GDP in the country be likely to fascinate foreign investors to invest in the particular country and it shows that interaction of openness level of the country and inflow of FDI has a positive and significant effect.

According to Ranjan and Agrawal (2011), the study is intended to determine the major Foreign Direct Investment (FDI) inflow determinants that show the capital flow to Brazil, Russia Federation, India and China in a globalization framework between the year 1975 and 2009. Panel data has been used in this research and methodology of this research are Random effect method, Fixed effect method, Common constant method, and Hausman Specification Test in order to capture the dynamic behaviour of the parameters and to provide more efficient estimation and information of the parameters. The result reveals that all of the factors potential to be determinants of FDI inflows except total labour force and gross capital formation in BRICS countries.

On the other hand, the study of Omankhanlen (2011) examined the effect of inflation and exchange rate and the bidirectional influences between FDI and economic growth in Nigeria. The ordinary least square regression method has been used in this research to investigate the relationship between inflation, exchange rate, FDI inflows and economic growth. The findings of this research shows that inflation does not have effect on FDI, however, the exchange rate has effect on FDI. The findings also reveals that the FDI also affected by economic growth which influenced by trade openness.

In the same year, the research of Cuyvers, Soeng, Plasmans, and Van Den Bulcke (2011) analyses the determinants that might influence inward FDI in Cambodia by referring to its economic, geographic, and political characteristics. The panel data analysis are used in this research and the methodology are Augmented Dickey-Fuller test statistics, pooled OLS model and the Random Effect model to estimate causal relationship between independents and dependent variable. The dependent variable in this research is inward of FDI while independent variable are market size, labour cost, borrowing costs, trade relations, exchange rates, country risk, regional integration, inflation rate and geographic distance. The result reveals that GDP and exchange rate have positive influence on inward of FDI, however, there is a negative correlation between geographic distance and level of FDI inflow.

According to Singhania and Gupta (2011), the study is to examine the determinants of foreign direct investment (FDI) in India. The time series analysis has been used in this study and the dependent variable is foreign direct investment while the independent variables are GDP, inflation rate, interest rate, patents, money growth and foreign trade. The study used ADF Test (Augmented Dickey-Fuller), Langrange Multiplier (LM) test, Whites test, and Autoregressive integrated moving average (ARIMA) models to find the regression line and thus presence of relationship between the variables. The finding shows that the significant determinant of FDI are GDP and Inflation rate. Moreover, policy of FDI in India changed during the time period of 1995 to 1997 have found significant influence on inflow of FDI.

Next, Gabriel (2012) examined the determinants and impact of FDI in Nigeria from 1970 through 2009. The methodology applied in the study are Vector Error Correction Model (VECM) and Granger causality to determine the nature of the relationship between FDI and its determinants and economic development on the one hand. The findings shows the main determinants of FDI inflow in Nigeria are the macroeconomic variables and openness of economic, however relationship of GDP and government size with FDI revealed positively but they are insignificant influence towards FDI. On 
INTERNATIONAL JOURNAL OF ACADEMIC RESEARCH IN BUSINESS AND SOCIAL SCIENCES Vol. 10, No. 6, June, 2020, E-ISSN: 2222-6990 @ 2020 HRMARS

the other hand, the long-run equilibrium relationship of FDI and GDP had been revealed through the analysis, however it found that FDI does not have significant effect on the growth of Nigeria economy during this period.

Yol and Teng (2012) investigates the domestic short-run and long-run factors that influence FDI flows into Malaysia using annual data over period of 1975-2006. The time series analysis has been used in this study and the variable are FDI, gross domestic production, exchange rate, openness, gross fixed capital formation, and export. The methodology used in this study are Johansen cointegration, Error-correction model, Augmented Dickey-Fuller (ADF), and Phillip-Peron (PP) test. The findings show that real exchange rate, gross domestic product and infrastructure have positively effect on FDI flow, however, exports has negatively impact on FDI flows in long run. Moreover, the study found that FDI flows is positively influence by openness and real exchange rate variables in short run.

According to Tintin (2013), the study investigate the determinants of FDI inflows in six Central and Eastern European countries (CEEC) over the 1996-2009 period. Another objective of this study is to examine whether the four investor countries (EU-15, the US, China, and Japan) differ in their determinant factors. Panel data analysis has been used in this research and the variables are FDI inflow, GDP, openness, distance, economic freedoms, political rights, civil liberties, and state fragility index. The methodology used in this study are panel OLS method, fixed effects method, and the White heteroscedasticity consistent standard errors. The results revealed the GDP, trade openness, EU membership, and institutions are positively significant on FDI inflows, and it show that the existence of notable differences in the determinant factors across four investor countries.

Bekhet and Al-Smadi (2014) has investigate macroeconomic factors that are affecting FDI inflows and examines the long-run and short-run causality relationships among the variables for the period of 1980-2011 in Jordan. The independent variables in this study are broad money supply, GDP, rate of inflation, and exchange rate while dependent variable is FDI inflows. The time series data analysis has been used and the methodology are Augmented Dickey-Fuller (ADF), Phillips-Perron (P$P)$, Johansen and Juselious, and Engel and Granger to testing the short-run causality relationships among variables. The study found that the macroeconomic factors and the inflow of FDI have a longrun relationship.

Next, Tang, Yip and Ozturk (2014) examined the determinants of FDI inflow of Malaysia in the electrical and electronic (E\&E) industry. The research has used time series data analysis and the methodology are bounds test approach, Augmented Dickey-Fuller (ADF), Phillips-Perron (PP) unit root test, Cointegration analysis, Granger causality analysis, error-correction model (ECM) and vector autoregression (VAR) model. The variables in this research are real FDI in the E\&E industry, real GDP, real exchange rate, financial development indicator, corporate income tax rate, social uncertainty indicator and macroeconomic uncertainty indicator. The research reveals that these variables are significantly affect the inflow of FDI. However, it shows that there is a negative impact between the interaction of corporate income tax and social uncertainty with inflow of FDI, while the remaining variable are positive related to inflow of FDI in E\&E sector.

The study of Valli and Masih (2014), has examines whether a long-run theoretical relationship does indeed exist between the level of inflation in South Africa and the amount of FDI eventually received by the country. Time series data analysis has been used in this research and the variables are FDI inflow, level of inflation, market size, trade openness, financial development, exchange rate volatility, and policy change. The methodology used in this research are vector autoregressive model (VAR), Vector Error Correction Model (VECM), Augmented Dickey-Fuller (ADF) test, Philips- Perron 
(PP) test, Johansen method and Engle-Granger method, Long-run Structural Modelling (LRSM) CUSUM, CUSUM SQUARE, Orthogonalized VDC and the Generalised VDC approach. The study reveals that the level of inflation increased will cause negative impact towards the FDI inflow, on the other hand, it indicate a long-run negative relationship between these two variables. Moreover, the study shows that a constant level of inflation and a better FDI inflows in South Africa have the degree of causality among them.

Alshami, Hussin and Azam (2015) has analysed the impact of inflation rate and GDP per capita on FDI inflows in United Arab Emirates (UAE). The time series data has been employed in this study from the period of 1980 to 2013. The independent variable are inflation rate and GDP per capita, while the dependent variable is inflow of Foreign Direct Investment. Methodology that applied on this research is auto regressive distributed lag ( $A R D L)$ model to examine the long-run relationship between the independent and dependent variables. The result shows that inflation does not have significant effect to the inflow of FDI, however, the GDP per capita is significantly positive impact to the inflow of FDI.

According to Mugableh (2015), the objective of study is to investigate equilibrium relationships between FDI inflows and their determinants. Time series data analysis has been used in this study and the independent variables are broadest money supply, consumer price index, exchange rates, gross domestic product, and trade, while the dependent variable is inflow of foreign direct investment. The unit root test, bounds F-statistics, the ARDL approach is used to analyse the variables in this study. The findings of the study show that exchange rates, gross domestic product, broadest money supply, and trade have positive impact on FDI inflows.

In the same year, the research of Xaypanya, Rangkakulnuwat, and Paweenawat (2015) was to investigate the significant determinant of foreign direct investment (FDI) in ASEAN3 and ASEAN5. This research apply the panel data analysis from the year 2000 to 2011 and the methodology are panel ordinary least square (POLS) estimation and panel unit root test. The result shows that infrastructure facility and level of openness have significant positive effects on FDI inflow, while inflation has negative effects on FDI inflow in ASEAN3. The significant determinants of induce FDI in ASEAN5 are market size and infrastructure. Moreover, the findings showed FDI in ASEAN5 remain attractive although the inflation rate has increased while level of openness has decreased.

According to Kasthuri (n.d.), the study has examine the impact on foreign direct investment due to growth and inflation of India. This research has used time series data from period of 15 years from 2000 - 2015 and the independent variables are GDP and Inflation rate while FDI is taken as dependent variable. A multiple regression models is used in the research to check the significant impact of inflation and GDP on FDI. Result of this research shows the gross domestic product has positive signal to the foreign direct investment. This result show that foreign direct investment is due to the country's GDP and inflation. FDI has positive relation with GDP and inflation, it implies that FDI will increase as the GDP rate and inflation rate has increased.

\section{Data Description}

The secondary data is used for analysis in this study, which is drawn from the World Development Indicator, World Bank. Relevant annual data retrieved from the official portal is a time series data and the sample periods are beginning in 1986 until 2015, with 30 observations. The dependent variable in this research is the net inflow of Foreign Direct Investment (FDI), while the independent 
INTERNATIONAL JOURNAL OF ACADEMIC RESEARCH IN BUSINESS AND SOCIAL SCIENCES

Vol. 10, No. 6, June, 2020, E-ISSN: 2222-6990 @ 2020 HRMARS

variables are inflation rate which measured by consumer price, GDP per capita growth which is the proxy of economic growth, and exchange rate.

\section{Econometric Model and Methodology \\ Model Specification}

The model used in this research is multiple linear regression model and examines the relationship between dependent variable and independent variable. Thus, the growth model for this research is as follows:

Where,

$$
F D I_{t}=\alpha+\beta_{1} I N F_{t}+\beta_{2} G D P_{t}+\beta_{3} E X R_{t}+\varepsilon t
$$

FDI= Foreign Direct Investment in Malaysia and Iran;

INF= Inflation rate in Malaysia and Iran;

GDP $=$ Gross Domestic Product (GDP) in Malaysia and Iran, and

$\mathrm{EXR}=$ Exchange rate in Malaysia and Iran.

In this multiple linear regression form, In representing the logarithm form, $\mathbf{t}$ is the year, $\boldsymbol{\alpha}$ representing a constant variable and the intercept of regression model such as $\boldsymbol{\beta}_{\mathbf{1}}, \boldsymbol{\beta}_{\mathbf{2}}$ and $\boldsymbol{\beta}_{\mathbf{3}}$ represent the slope regression of coefficient. Other that, $\boldsymbol{\varepsilon}_{\mathrm{t}}$ is the error term and a random variable at the time which represents the omitted determinants that other variables than the INF, GDP and EXR. The application of regression form of (1) is due to the different scales presented in sample data.

\section{Methodology}

\section{Unit Root Tests}

Augmented Dickey Fuller (ADF) test used by the researcher which developed by Dickey and Fuller (1981) to test the data or the characteristic of variable whether stationary or non-stationary. The hypotheses for Augmented Dickey Fuller (ADF) test which show as $\mathrm{H}_{0}: \alpha=0$ (non-stationary) and $\mathrm{H}_{1:} \quad \alpha \neq 0$ (stationary). The rejection rule for the ADF test is the null hypothesis can be rejected if the computed test statistics larger than the critical value at a significance level which indicate that the variables are stationary and integrated at the corresponding orders. Otherwise, when computed test statistics smaller than the critical value, the null hypothesis cannot be rejected and shows the variable is non-stationary and has a unit root.

\section{Johansen and Juselius Co-integration Test}

After identifying the stationary linear combination of non-stationary random variables is existing, the variables combined are co-integrated. Next, Johansen-Juselius will be applied to test the variables with existed the long term equilibrium relationship in this study. According to Johansen and Juselius (1990), the procedure is a representation of the approach of analyzing multivariate cointegration system. The study is allowed to conduct the test if all the variables are stationary at level $\mathrm{I}(0)$ or I(1). It used the first difference in the vector autoregressive model. The formula is shown below:

$$
Y_{t}=A_{1} Y_{t-1}+A_{2} Y_{t-2}+\ldots \ldots+A_{n} Y_{t-n}+\varepsilon_{t}
$$


Whereas $t Y$ is lag length $n(p \times 1)$ vector endogenous

$$
\Delta Y_{t}=\sum_{j=1}^{n=1} \pi, \Delta Y_{t-j}+\pi Y_{t-n}+\varepsilon_{t}
$$

$\pi j$ is a short term adjusting coefficient to describe short-term relationship, while $\pi$ is long term shock vector that consist of long term information hint in the regression to test those variables whether existence long term equilibrium relationship or not.

\section{Vector Error Correction Model (VECM)}

The Vector Error Correction (VECM) model is applied for examining the short run and long run relationship between the variables. Deviations from equilibrium and short run changes in each of the variables will regulated by VECM model. The error correction model is categorized as the multiple time series model and it usually used for the data that consist of long-run stochastic trend variables which called co-integration. Besides, the short-run dynamics will be affected by the deviation of the last-period error which from the long run equilibrium. The speed of a dependent variable can be easily estimated by error correction model when it change into the equilibrium after changes in another variable. Hence, ECMs can straightly to estimate the speed at which a dependent variable returns to equilibrium after a change in other variables.

If the VAR framework need to be modified when the time series are not stationary, the Vector Error Correction Model (VECM) will be applied to estimate the relationship among the series consistently. Moreover, the primary differences are covariance stationary but the variables are not when an equation may be modelled by a VECM.

\section{Granger Causality Tests}

According to Granger (2001), the original application of Granger causality test is to determine the direction of cause and the effect for a set of variables. In the Johansen and Juselius (JJ) test, if the more than one cointegrating vector are found, the Granger causality test will need to perform via the VECM. In contrast, Granger causality test will performed under the Vector autoregression (VAR) model if there is no cointegrating vector found in Johansen and Juselius (JJ) test. In the Granger causality test, there are only four possible result will be occurred. Firstly, the unidirectional relationship occurs if the dependent variable does Granger causes to the independent variable. Next, the second scenario also shows a unidirectional relationship but it is the independent variable Granger cause to the dependent variable in this scenario. Moreover, when the dependent variable and independent variable are Granger caused to each other, there will be occur a bi-directional relationship between dependent and independent variable. Lastly, the non-directional relationship will be occurred if both dependent and independent variable do not Granger cause to each other. The hypothesis can be developed as $\mathrm{H}_{0}$ : $\mathrm{X}$ does not Granger cause on $\mathrm{Y}$ and alternatively, $\mathrm{H}_{1}$ : $\mathrm{X}$ does Granger cause on $Y$.

If the probability value ( $\mathrm{p}$-value) is smaller than the critical value a significant level, $\mathrm{H}_{0}$ would be rejected based on the rejection rules and the causally effect will happened. This indicate that the independent variable does Granger cause the dependent variable. In contrast, when the p-value is greater than the critical value at significant level, $\mathrm{H}_{0}$ cannot be rejected, this means that the 
INTERNATIONAL JOURNAL OF ACADEMIC RESEARCH IN BUSINESS AND SOCIAL SCIENCES Vol. 10, No. 6, June, 2020, E-ISSN: 2222-6990 @ 2020 HRMARS

independent variable does not Granger cause the dependent variable. Hence, there is no causality effect happen between independent and dependent variable.

\section{Results and Discussions}

\section{Unit Root Test - Augmented-Dickey Fuller (ADF) test}

It is essential for the ADF test to test the stationary of variables and it is compulsory to pass the test in order to proceed to the Johansen and Juselius cointegration test. The series tested of Malaysia (Table 1) and Iran (Table 2) in this study are integrated in zero or first order, which is $/(0)$ or $/(1)$. As each of the series are stationary, Johansen and Juselius Cointegration test able conducted to trace the existence of long run relationship between variables of inflation rate (INF), gross domestic product (GDP), foreign direct investment (FDI), and exchange rate (EXR) in Malaysia and Iran.

Table 1: Results of ADF Unit Root Test in Malaysia from 1986 to 2015

\begin{tabular}{|c|c|c|}
\hline \multicolumn{3}{|c|}{ Test statistics } \\
\hline \multirow[t]{2}{*}{ Variables } & \multicolumn{2}{|c|}{ ADF test } \\
\hline & 1 & $T \& 1$ \\
\hline \multicolumn{3}{|l|}{ A: Level } \\
\hline INF & $-4.302823(0)^{* *}$ & $-4.342573(0)^{* *}$ \\
\hline LGDP & $-1.349502(0)$ & $-2.035797(0)$ \\
\hline LFDI & $-3.952214(0)^{* *}$ & $-4.605261(0)^{* *}$ \\
\hline EXR & $-1.276526(0)^{* *}$ & $-1.680198(0)^{* *}$ \\
\hline \multicolumn{3}{|l|}{ B: First difference } \\
\hline$\Delta \mathrm{INF}$ & $-6.170288(0)^{* *}$ & $-6.148378(0)^{* *}$ \\
\hline$\Delta$ LGDP & $-4.431693(0)^{* *}$ & $-4.442348(0)^{* *}$ \\
\hline$\Delta$ LFDI & $-6.014374(1)^{* *}$ & $-7.869410(0)^{* *}$ \\
\hline$\triangle \mathrm{EXR}$ & $-3.976477(0)^{* *}$ & $-3.857687(0)^{* *}$ \\
\hline
\end{tabular}

Notes: The asterisks, ${ }^{* *}$ denote statistically significant at $5 \%$ level of significance. Number in the parentheses, ( ), is the number of lags. Lag lengths for the ADF unit root test are based on the Schwarz Info Criterion. I represents intercept and T \& I represents trend and intercept. The null hypothesis under ADF test are the presence of a unit root. 
INTERNATIONAL JOURNAL OF ACADEMIC RESEARCH IN BUSINESS AND SOCIAL SCIENCES Vol. 10, No. 6, June, 2020, E-ISSN: 2222-6990 @ 2020 HRMARS

Table 2: Results of ADF Unit Root Test in Iran from 1986 to 2015

\begin{tabular}{|c|c|c|}
\hline \multicolumn{3}{|c|}{ Test statistics } \\
\hline \multirow[t]{2}{*}{ Variables } & \multicolumn{2}{|c|}{ ADF test } \\
\hline & 1 & $\mathrm{~T} \& \mathrm{I}$ \\
\hline \multicolumn{3}{|l|}{ A: Level } \\
\hline INF & $-3.205416(0)^{* *}$ & $-3.275635(0)$ \\
\hline LGDP & $-0.909354(0)$ & $-2.245256(0)$ \\
\hline FDI & $-1.416462(0)$ & $-2.138833(0)$ \\
\hline LEXR & $-1.022075(0)$ & $-2.104582(0)$ \\
\hline \multicolumn{3}{|l|}{ B: First difference } \\
\hline$\Delta I N F$ & $-5.791764(0)^{* *}$ & $-5.696519(0)^{* *}$ \\
\hline$\Delta \mathrm{LGDP}$ & $-3.814921(0)^{* *}$ & $-3.585825(0)^{* *}$ \\
\hline$\Delta \mathrm{FDI}$ & $-4.911553(0)^{* *}$ & $-4.856939(0)^{* *}$ \\
\hline$\Delta$ LEXR & $-5.067025(0)^{* *}$ & $-5.576645(0)^{* *}$ \\
\hline
\end{tabular}

Notes: The asterisks, ${ }^{* *}$ denote statistically significant at $5 \%$ level of significance. Number in the parentheses, ( ), is the number of lags. Lag lengths for the ADF unit root test are based on the Schwarz Info Criterion. I represents intercept and T \& I represents trend and intercept. The null hypothesis under ADF test are the presence of a unit root.

\section{Johansen and Juselius Cointegration Test (JJ Test)}

The Johansen and Juselius Cointegration test are conducted in the study in order to determine the presence of the long run relationship among all of the variables. Trace test and Maximum Eigenvalue ( $\lambda$ max) test is consisted in JJ test, the null hypothesis $(r=0)$ of Trace and Maximum Eigenvalue test shows that the absence of cointegration between variables in long run, while the alternative hypothesis indicates there is cointegration between variables in long run.

Table 3: Results for Johansen and Juselius Cointegration Test (Malaysia)

\begin{tabular}{cccccc}
\hline \multirow{2}{*}{ Null } & \multirow{2}{*}{ Alternative } & \multicolumn{2}{c}{ Trace } & \multicolumn{2}{c}{ Max-Eigen } \\
\cline { 3 - 6 } & & Unadjusted & $95 \% \mathrm{CV}$ & Unadjusted & $95 \% \mathrm{CV}$ \\
\hline $\mathrm{r}=0$ & $\mathrm{r}=1$ & $77.46310^{*}$ & 54.07904 & $35.46935^{*}$ & 28.58808 \\
\hline $\mathrm{r}<1$ & $\mathrm{r}=2$ & $41.99384^{*}$ & 35.19275 & 22.20623 & 22.29962 \\
\hline $\mathrm{r}<2$ & $\mathrm{r}=3$ & 19.78762 & 20.26184 & 14.82260 & 15.89210 \\
\hline $\mathrm{r}<3$ & $\mathrm{r}=4$ & 4.965016 & 9.164546 & 4.965016 & 9.164546 \\
\hline
\end{tabular}

Notes: The asterisks $(*)$ denote statistically significant at $5 \%$ level of significance. The $k$ is the lag length and $r$ is the cointegrating vector(s). Chosen $r$ number of cointegrating vectors that are significant under both tests.

Based on the result in Table 3, the null hypothesis are rejected at 5 percent significant level and there is only 1 cointegrating vector between variables in the long run in a case of Malaysia. A similar findings also found in Iran as showed in Table 4. The result of Maximum Eigenvalue statistic will be followed in this study as it more powerful than Trace statistic according to Johansen and Juselius (1992). 
INTERNATIONAL JOURNAL OF ACADEMIC RESEARCH IN BUSINESS AND SOCIAL SCIENCES Vol. 10, No. 6, June, 2020, E-ISSN: 2222-6990 @ 2020 HRMARS

Table 4: Results for Johansen and Juselius Cointegration Test (Iran)

\begin{tabular}{llllll}
\hline \multirow{2}{*}{ Null } & \multirow{2}{*}{ Alternative } & \multicolumn{2}{c}{ Trace } & \multicolumn{2}{c}{ Max-Eigen } \\
\cline { 3 - 6 } & & Unadjusted & $95 \% \mathrm{CV}$ & Unadjusted & $95 \% \mathrm{CV}$ \\
\hline $\mathrm{r}=0$ & $\mathrm{r}=1$ & $69.55140 *$ & 63.87610 & $33.42924 *$ & 32.11832 \\
\hline $\mathrm{r}<1$ & $\mathrm{r}=2$ & 36.12216 & 42.91525 & 18.98552 & 25.82321 \\
\hline $\mathrm{r}<2$ & $\mathrm{r}=3$ & 17.13664 & 25.87211 & 10.51088 & 19.38704 \\
\hline $\mathrm{r}<3$ & $\mathrm{r}=4$ & 6.625754 & 12.51798 & 6.625754 & 12.51798 \\
\hline
\end{tabular}

Notes: The asterisks $(*)$ denote statistically significant at $5 \%$ level of significance. The $k$ is the lag length and $r$ is the cointegrating vector(s). Chosen $r$ number of cointegrating vectors that are significant under both tests.

In conclusion, the both results for Johansen and Juselius Cointegration Test of Malaysia and Iran shown that there is only cointegrating vector between the variables in long run. The variables will be proceed to test with VECM to examine long run relationship and the magnitudes between dependent and independent variables.

\section{Vector Error Correction Model (VECM) and Granger Causality}

The Vector Error Correction Model (VECM) is to construct the Error Correction Term (ECT), the ECT in VECM is used to find out the speed of adjustment that needed to adjust the variables return back to equilibrium in long run. There are 3 criteria for ECT to be fulfilled which are less than 1, negative value and the t-statistics is significant at 5 percent significance level critical value. Granger causality test will implemented after obtain the long run equation from VECM, it is used to find the short run relationship among all the variables.

Table 5: Results for Granger Causality Test (Malaysia)

\begin{tabular}{|c|c|c|c|c|c|c|}
\hline \multirow{2}{*}{$\begin{array}{c}\text { Dependent } \\
\text { Variable }\end{array}$} & $\Delta \mathrm{INF}$ & $\Delta \mathrm{LGDP}$ & $\Delta \mathrm{LFDI}$ & $\Delta \mathrm{EXR}$ & \multicolumn{2}{|c|}{$\mathrm{ECT}$} \\
\hline & \multicolumn{4}{|c|}{$x^{2}$ statistic } & Coefficient & t-ratio \\
\hline$\Delta \mathrm{INF}$ & - & $\begin{array}{c}1.630948 \\
(0.2016)\end{array}$ & $\begin{array}{c}1.866516 \\
(0.1719)\end{array}$ & $\begin{array}{c}2.463173 \\
(0.1165)\end{array}$ & -0.981860 & -3.29139 \\
\hline$\Delta \mathrm{LGDP}$ & $\begin{array}{r}0.650971 \\
(0.4198) \\
\end{array}$ & - & $\begin{array}{c}0.214235 \\
(0.6435)\end{array}$ & $\begin{array}{c}1.569403 \\
(0.2103)\end{array}$ & 0.023630 & 0.82630 \\
\hline$\Delta \mathrm{LFDI}$ & $\begin{array}{c}0.454141 \\
(0.3589) \\
\end{array}$ & $\begin{array}{l}5.393462 \\
(0.0202)^{*}\end{array}$ & - & $\begin{array}{r}1.922207 \\
(0.1656) \\
\end{array}$ & -0.416165 & -1.76757 \\
\hline$\Delta \mathrm{EXR}$ & $\begin{array}{c}0.007953 \\
(0.9289)\end{array}$ & $\begin{array}{c}1.002775 \\
(0.3166)\end{array}$ & $\begin{array}{r}0.001300 \\
(0.9712)\end{array}$ & - & -0.061538 & -0.89893 \\
\hline
\end{tabular}

Notes: The $x^{2}$ statistics tests the joint significance of the lagged values of the independent variables, and the significance of the error correction term(s). $\Delta$ is the first different operator. The asterisks $\left({ }^{*}\right)$ denote statistically significant at 5 percent level. Values in in parentheses indicate the probability value.

Based on the empirical results, INF is the only one variable which fulfilled the criteria of ECT which has a coefficient of -0.9819 , which is negative value and less than one, and with a t-statistic of -3.291 which less than the critical value of -1.96 at 5 percent significance level. The result showed that it 
INTERNATIONAL JOURNAL OF ACADEMIC RESEARCH IN BUSINESS AND SOCIAL SCIENCES Vol. 10, No. 6, June, 2020, E-ISSN: 2222-6990 @ 2020 HRMARS

takes 1.08 years to adjust back to the long run equilibrium as the speed of adjust is about $98.19 \%$ in annually. Furthermore, there is one unidirectional short run causality which running from LFDI to LGDP, it indicated that LFDI does granger cause LGDP.

Table 6: Results for Granger Causality Test (Iran)

\begin{tabular}{|c|c|c|c|c|c|c|}
\hline \multirow{2}{*}{$\begin{array}{c}\text { Dependent } \\
\text { Variable }\end{array}$} & $\Delta \mathrm{INF}$ & $\Delta \mathrm{LGDP}$ & $\Delta \mathrm{FDI}$ & $\Delta$ LEXR & \multicolumn{2}{|c|}{ ECT } \\
\hline & \multicolumn{4}{|c|}{$x^{2}$ statistic } & Coefficient & t-ratio \\
\hline$\Delta \mathrm{INF}$ & - & $\begin{array}{c}0.011012 \\
(0.9164) \\
\end{array}$ & $\begin{array}{c}1.763318 \\
(0.1842) \\
\end{array}$ & $\begin{array}{c}1.804132 \\
(0.1792) \\
\end{array}$ & -0.540151 & -2.00390 \\
\hline$\Delta \mathrm{LGDP}$ & $\begin{array}{c}0.574540 \\
(0.4485)\end{array}$ & - & $\begin{array}{c}0.901075 \\
(0.3425)\end{array}$ & $\begin{array}{c}0.053588 \\
(0.8169)\end{array}$ & 0.008053 & 1.41927 \\
\hline$\Delta \mathrm{FDI}$ & $\begin{array}{c}2.385954 \\
(0.1224)\end{array}$ & $\begin{array}{c}1.382479 \\
(0.2397)\end{array}$ & - & $\begin{array}{c}0.347490 \\
(0.5555)\end{array}$ & -38889379 & -1.53419 \\
\hline$\Delta$ LEXR & $\begin{array}{c}0.067964 \\
(0.7943)\end{array}$ & $\begin{array}{c}0.601301 \\
(0.4381)\end{array}$ & $\begin{array}{r}0.004717 \\
(0.9452)\end{array}$ & - & 0.011513 & 0.62584 \\
\hline
\end{tabular}

Notes: The $x^{2}$ statistics tests the joint significance of the lagged values of the independent variables, and the significance of the error correction term(s). $\Delta$ is the first different operator. The asterisks $\left({ }^{*}\right)$ denote statistically significant at 5 percent level. Values in in parentheses indicate the probability value.

From the tabulated result, among the variables, there is only INF fulfilled the criteria of ECT as its estimated coefficient is -0.54 which is negative value and less than one. Furthermore, as the t-statistic of INF is greater than its critical value which $-2.004>-1.96$, hence it is significant at 5 percent significance level. Based on the result, the speed of adjustment is about $54.02 \%$ in annually which indicate that it will take 1.85 years to adjust back in the long run equilibrium. Moreover, there is no granger causality among the variables in short run as all of the $p$-value of variables are greater than 5 percent significance level. In other word, it denote that null hypothesis cannot be rejected as the $\mathrm{p}$-value is greater than critical value.

In short, based on the results, it showed that Malaysia and Iran both have one ECT in the VECM, however the speed of adjustment of both countries are different. The speed of adjustment for long run equilibrium in Malaysia is 1.08 years while in Iran is 1.85 years. Besides, there is only one unidirectional causality among the variable in Malaysia but there is no causality relation among the variables in Iran. Thus, this results confirmed that inflation has an impact on foreign direct investment, particularly in the long term.

\section{Conclusion}

The findings of this study shows that the inflation rate has negative effects on the foreign direct investment in the long run. As foreign direct investment is one of the important factor which contributed to a country's economic growth, the government should implement the supply side policies to reduce the inflation and therefore increase the foreign direct investment. The goal of supply side policies is to enhance the long term of competitive strength and productivity. The implementation of supply side policies enable to decrease the pressure of the inflationary in long term and the economic competitiveness will be ameliorated, with the terms of productivity and aggregate supply has been increased by government. The higher competitiveness of economic of the 
country will attract more foreign investors to invest on it, thus the foreign direct investment of the particular country will be increase.

Furthermore, the fiscal policy should be used by government which to regulates its spending level and tax rate in order to reduce the inflation. By implemented the fiscal policy, government able to increase the tax rate and decrease the government expenditure in order to reduce the money out of the economy. A contractionary fiscal policy can be employ by the government to overcome the inflationary problem as the budget surplus will be generated by the contractionary fiscal policy to decrease the aggregate spending. Therefore, the decrease of inflation may lead to a greater inflow of foreign direct investment.

Besides, government should use the contractionary monetary policy to control the inflation. The contractionary monetary policy is target to decrease the money supply with cut down the bond price and increase the interest rates so as to reduce spending. Through the monetary policy, government can regulate the central bank reserves issued to commercial banks which able to irritate bank loans and investment to support the spending of government and folk. Reduction on spending and the aggregate demand can help the government to suppresses inflation and subside the inflationary pressures. Moreover, government impose a higher interest rate will also decrease the aggregate demand, and thus it will has a downward effect to inflation.

\section{References}

Alshamsi, K. H., Hussin, M., \& Azam, M. (2015). The impact of inflation and GDP per capita on foreign direct investment: the case of United Arab Emirates. Investment Management and Financial Innovations (open-access), 12(3), 132-141.

Ang, J. B. (2008). Determinants of foreign direct investment in Malaysia. Journal of policy modeling, 30(1), 185-189.

Bahmani-Oskooee, M. (2005). History of the Rial and Foreign Exchange Policy in Iran. Iranian Economic Review, 10(14), 1-20.

Bank Negara Malaysia. (2009). Economic Developments in 2009. Retrieved from https://www.bnm.gov.my/files/publication/ar/en/2009/cp01.pdf

Breitung, J., \& Pesaran, M. H. (2005). Unit roots and cointegration in panels. Deutsche Bundesbank Discussion Paper, Series 1: Economic Studies No. 42.

Brekhet, H. A., \& Al-smadi, R. W. (2014). Determining the causality relationship amongFDI determinants: evidence from Jordan. International Journal of Sustainable Economy, 6(3), 261274.

Callen, T. (2008). Back to Basics-What Is Gross Domestic Product?. Finance \& Development, 45(4), 48.

ÇEviş, I., \& Camurdan, B. (2007). The economic determinants of foreign direct investment in developing countries transition economies. The Pakistan Development Review, 285-299.

Choong, C. K., \& Lam, S. Y. (2010). The determinants of foreign direct investment in Malaysia: A revisit. Global Economic Review, 39(2), 175-195.

Clegg, J., \& Scott-Green, S. (1999). The determinants of new FDI capital flows into the EC: A statistical comparison of the USA and Japan. Journal of Common Market Studies, 37, 597-616.

Cuyvers, L., Soeng, R., Plasmans, J., \& Van Den Bulcke, D. (2011). Determinants of foreign direct investment in Cambodia. Journal of Asian Economics, 22(3), 222-234.

De Mello, L. R. (1997). "Foreign Direct Investment in Developing Countries and Growth: A Selective Survey." The Journal of Development Studies 34: 1-34. 
INTERNATIONAL JOURNAL OF ACADEMIC RESEARCH IN BUSINESS AND SOCIAL SCIENCES

Vol. 10, No. 6, June, 2020, E-ISSN: 2222-6990 @ 2020 HRMARS

Denisia, V. (2010). Foreign Direct Investment Theories: An Overview of the Main FDI Theories. European Journal of Interdisciplinary Studies, 2(2), 104.

Dickey, D. A., \& Fuller, W. A. (1981). Likelihood ratio statistics for autoregressive time series with a unit root. Econometrica: Journal of the Econometric Society, 1057-1072.

Dunning, J. H. (1979). Explaining changing patterns of international production: in defence of the eclectic theory. Oxford bulletin of economics and statistics, 41(4), 269-295.

Dunning, J. H. (1988): "The Eclectic Paradigm of International Production: A restatement and some possible extensions", in Journal of International Business Studies issue 19 (Spring).

Dunning, J. H. (1994). Re-evaluating the Benefits of Foreign Direct Investment. Transnational Corporations, 3(1), 23-51.

Dunning, J. H. (2000). The eclectic paradigm as an envelope for economic and business theories of MNE activity. International business review, 9(2), 163- 190.

Furuoka, F., \& Munir, Q. (2014). Unemployment and Inflation in Malaysia: Evidence from Error Correction Model. Malaysian Journal of Business and Economics (MJBE), 1(1).

Gabriel, A. M. (2012). The determinants and impacts of foreign direct investment in Nigeria. International Journal of Business and Management, 7(24), 67.

Granger, C. W. J. (2001). Investigating causal relations by econometric models and cross-spectral methods. ECONOMETRIC SOCIETY MONOGRAPHS, 33, 31- 47.

Hargreaves, S. (2012). U.S. tightens oil sanctions on Iran. Retrieved from http://money.cnn.com/2012/03/30/news/international/Iran-sanctions/index.htm

Hjalmarsson, D. (2013). Macroeconomic volatility as determinants of FDI: A source country perspective.

Johansen, S., \& Juselius, K. (1990). Maximum likelihood estimation and inference on cointegrationwith applications to the demand for money. Oxford Bulletin of Economics and statistics, 52(2), 169-210.

Khan, G. S., \& Mitra, P. (2014). A Causal Linkage between FDI Inflows with Select Macroeconomic Variables in India - An Econometric Analysis. IOSR Journal of Economics and Finance, 5(5), 2321-5933.

Kok, R., \& Ersoy, A. B. (2009). Analyses of FDI determinants in developing countries. International Journal of Social Economics, 36(1/2), 105-123.

Lily, J., Kogid, M., Mulok, D., Sang, T. L., \& Asid, R. (2014). Exchange rate movement and foreign direct investment in Asean economies. Economics Research International, 2014.

Mandal, S. K., \& Madheswaran, S. (2010). Causality between energy consumption and output growth in the Indian cement industry: an application of the panel vector error correction model (vecm). Energy Policy, 38,6560-65.

Mohammad, A. S. (2015). Why is the dollar surging in Iran? Retrieved from https://www.almonitor.com/pulse/originals/2015/12/dollar-rate-surges-iran-rial-market.html

Moosa, I. (2002). Foreign direct investment: theory, evidence and practice. New York, USA: Palgrave.

Mugableh, M. I. (2015). Time series analysis of inward foreign direct investment function in Malaysia. Procedia-Social and Behavioral Sciences, 172, 679-685.

Omankhanlen, A. E. (2011). The effect of exchange rate and inflation on foreign direct investment and its relationship with economic growth in Nigeria. EA1, 1.

Onyeiwu, S., \& Shrestha, H. (2004). Determinants of foreign direct investment in Africa. Journal of Developing Societies, 20(1-2), 89-106. 
INTERNATIONAL JOURNAL OF ACADEMIC RESEARCH IN BUSINESS AND SOCIAL SCIENCES

Vol. 10, No. 6, June, 2020, E-ISSN: 2222-6990 @ 2020 HRMARS

Otto, B. (2015). Malaysia's 2015 GDP Expected at Low End of Forecast. Retrieved from https://www.wsj.com/articles/malaysias-2015-gdp-expected-at-low-end-of-forecast1441979130

Ow, K. Y. (2015). Determinants of foreign direct investment in the manufacturing sector of Sarawak.

Ranjan, V., \& Agrawal, G. (2011). FDI inflow determinants in BRIC countries: A panel data analysis. International Business Research, 4(4), 255.

Romer, P. M. (1990). “Endogenous Technological Change”. Journal of Political Economy, 98, S71S102.

Sidhu, J. S. (2015). Pressure on currency war. The Star Online. Retrieved from https://www.thestar.com.my/business/business-news/2015/01/31/pressure-on-currencywar/

Singhania, M., \& Gupta, A. (2011). Determinants of foreign direct investment in India. Journal of international trade law and policy, 10(1), 64-82.

Tang, C. F., Yip, C. Y., \& Ozturk, I. (2014). The determinants of foreign direct investment in Malaysia: A case for electrical and electronic industry. Economic Modelling, 43, 287-292.

Tintin, C. (2013). The determinants of foreign direct investment inflows in the Central and Eastern European Countries: The importance of institutions. Communist and Post- Communist Studies, 46(2), 287-298.

Valli, M., \& Masih, M. (2014) Is there any causality between inflation and FDI in an 'inflation targeting'regime? Evidence from South Africa. (No. 60246). University Library of Munich, Germany.

Vernon, R. (1966), International Investment and International Trade in Produce Cycle, Quarterly Journal of Economics 80, pp.190-207.

Wijeweera, A., \& Mounter, S. (2008). A VAR analysis on the determinants of FDI inflows: The case of Sri Lanka. Applied Econometrics and International Development, 8(1), 189-198.

World Bank Group. (2017). World Development Indicators. Retrieved from https://data.worldbank.org/indicator/FP.CPI.TOTL.ZG?locations=MY

Xaypanya, P., Rangkakulnuwat, P., \& Paweenawat, S. W. (2015). The determinants of foreign direct investment in ASEAN: The first differencing panel data analysis. International Journal of Social Economics, 42(3), 239-250.

Yol, M. A., \& Teng, N. T. (2012). Estimating the domestic determinants of foreign direct investment flows in Malaysia: Evidence from cointegration and error- correction model. Jurnal pengurusan (UKM Journal of Management), 28.

Zakaria, Z., Hussin, Z., Bin Noordin, N., \& Sawal, Z. H. M. (2010). Financial crisis of 1997/1998 in Malaysia: causes, impacts and recovery plans. Voice of Academia, 5(1), 79-96. 